\title{
DISABLING PNEUMOCONIOSIS FROM LIMESTONE DUST
}

\author{
BY
}

\author{
A. T. DOIG
}

H.M. Medical Inspector of Factories

(RECEIVED FOR PUBLICATION OCTOBER 4, 1954)

Limestone dust is generally regarded as being relatively harmless. In this paper I wish to record eight cases of pneumoconiosis in limestone workers, in all of which limestone played the sole or principal aetiological part.

My attention was first drawn to the condition in November, 1950, when I saw the chest radiograph of a patient whose occupation was limestone crushing. The appearances were most suggestive of pneumoconiosis.

\section{Pneumoconiosis in a Limestone Grinder}

Case 1.-The patient, A. W., was 52 years of age in 1950. After spending two years as a blacksmith's apprentice and six months as a labourer in a whinstone quarry, he served through World War I. He then worked for one year as a diver's assistant and six months as a shipyard labourer before becoming a limestone grinder in 1921. He continued at this work until 1947 when he left to receive medical attention for a swelling in the left upper part of the neck, which had been gradually increasing in size for a year, and for blockage of the left nostril of three months' duration. A tumour was found in the posterior nares which on biopsy was reported to be a fibrosarcoma. $X$-ray examination of the lungs showed bilateral mottling which might have been due to pulmonary metastases or pneumoconiosis. From January until July, 1947, he was given $x$-ray therapy to the nasopharynx and to both sides of the neck, but not to the chest. In November, 1947, his condition was satisfactory and there was no evidence of a primary lesion or of secondary glands. The $x$-ray appearances, however, had not changed much since then, although about March, 1950 (Fig. 1), he complained of increasing breathlessness and gave up the light job of storekeeper he had held for the previous two years. Examination in December, 1952, showed that dyspnoea was absent at rest, but present on slight exercise. Cough and sputum were troublesome in the morning, but not during the day. He was in poor general condition, being thin and pale. There was no finger clubbing. The chest was flattened, expansion $1 \frac{1}{4}$ in., percussion note hyper-resonant, breath sounds vesicular, and post-tussic crepitations, audible at both bases, were particularly numerous on the right side.

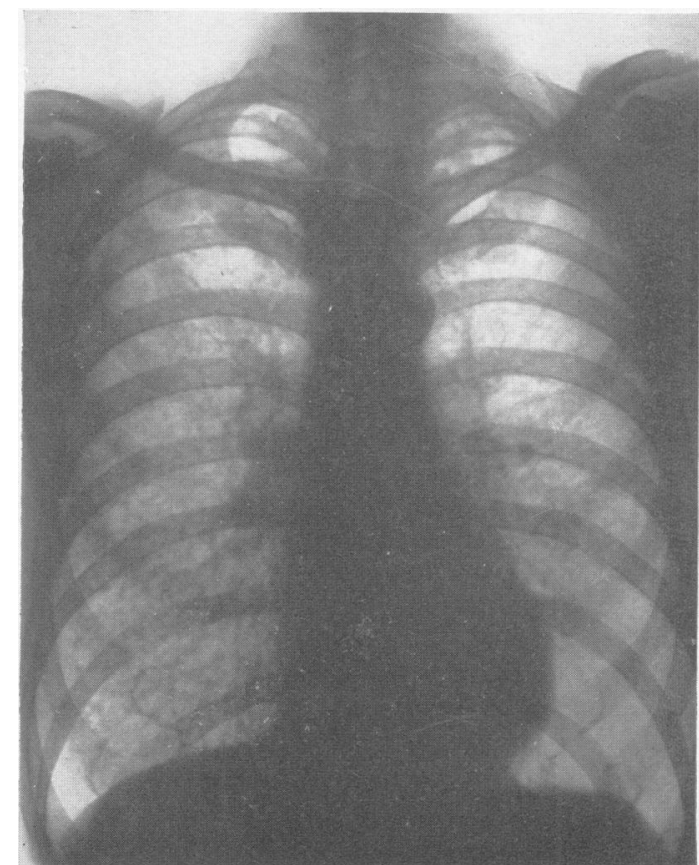

FIG. 1.-Case 1 in March, 1950, aged 52 years limestone grinder for 26 years.

The heart was normal but the peripheral vessels showed evidence of arteriosclerosis. There were no enlarged cervical glands and the throat and nose seemed normal. An $x$-ray examination in March, 1950 , showed a normal appearance of the thoracic skeleton, heart, and diaphragm. Nodular opacities were present in both lungs, fairly uniform in size ( 3 to $4 \mathrm{~mm}$. in diameter), profuse and evenly distributed throughout the right lung but present on the left side mainly in the mid-zone. At the right infraclavicular area there were some patches of coalescence, one of which measured $1 \mathrm{~cm}$. in diameter. At the left base the translucency was much increased denoting emphysema (or possibly a localized pneumothorax). The appearance was that of early complicated 


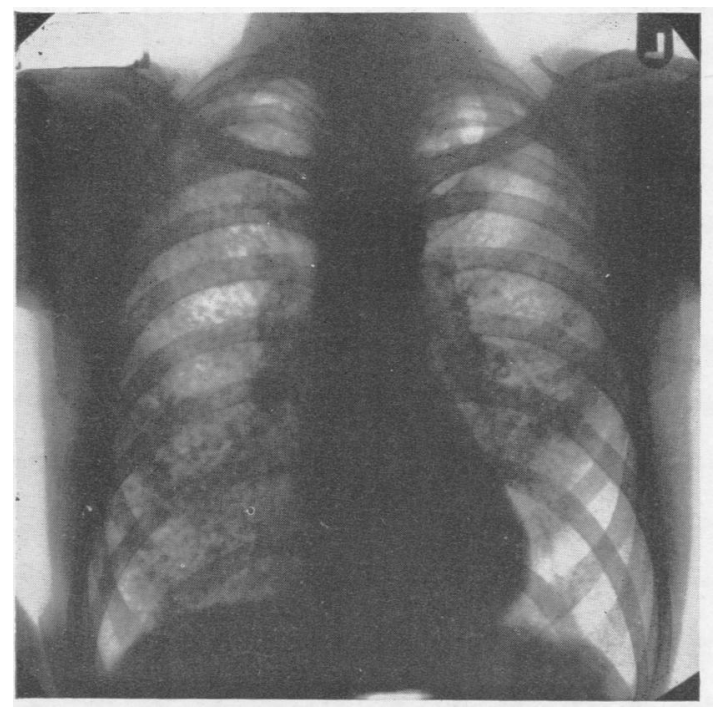

FIG. 2.-Case 1 in May, 1954.

pneumoconiosis, category (3)A.* In May, 1954, the nodulation had become denser, and, in places, a little larger, with slightly increased coalescence but without the formation of definite masses. The hilar glands now showed egg-shell calcification and some of the parenchymal nodular elem $2 n t s$ were proably also partially calcified (Fig. 2).

The patient has been granted a certificate of total disability on account of silicosis from the Pneumoconiosis Medical Panel.

\section{Geology of Limestones}

Limestones consist predominantly of calcium carbonate and occur widely in rocks of all ages with the exception of Pre-Cambrian rocks in which they are seldom found. They are formed in three principal ways. Organic limestones are built up from the skeletal remains of a great variety of organisms, plant as well as animal, deposits in the form of calcite being by far the most abundant. Chemical limestones are formed by the precipitation of calcium carbonate. Clastic limestones are formed by erosion and redeposition of preformed limestones. They are of less importance. Special varieties of limestones include magnesium limestone, which contains a notable proportion of magnesium carbonate, and dolomite rock, a limestone in which the mineral dolomite forms the bulk of the rock, dolomite being the double salt, calcium-magnesium carbonate.

\footnotetext{
* The classification adopted is the International Scheme for the
Classification of Radiographs in Some of the Pneumoconioses, recommended in the Report of the Third International Conference of Experts on Pneumoconiosis (Sydney, 1950).
}

Limestones play an important part in a wide variety of industries. They are extensively employed in agriculture for improving the soil, either as the pulverized natural rock (ground limestone), or, after burning, as lime, also for poultry grit, and in the feeding of pigs and other farm stock. In the building and allied trades limestones form an important supply of building stone, as, for example, Portland stone, which is the principal building stone used in London. They are also used for monumental work, for making artificial stone, as aggregates for concrete, as roadstone, and for making Portland and other kinds of cement. Some limestones take a high polish and are commercially known as marbles. In the strict petrological sense, however, marbles are crystalline rocks composed of interlocking grains of calcite. They result from the crystallization of pure limestones under the influence of increased temperature and pressure, and hence are metamorphic rocks. In the chemical industry limestone is used as a base, as a source of lime, for the manufacture of carbon dioxide, and for making calcium compounds. It is an important raw matcrial in the metal industry, being used as a flux in various smelting and meling operations, for instance, in the working of blast furnaces. In the coal-mines powdered limestone is extensively used for stone dusting to reduce the risk of explosions. To a less extent, it is employed in the manufacture of paints and distemper, of paper, glass, soap, pottery, medicinal and pharmaceutical preparations, explosives, in the textile and printing trades, in railway engineering, in furnace construction, and as a mild abrasive in metal polishing.

\section{Brief Review of the Literature}

According to Forbes, Davenport, and Morgis (1950) many authorities considered that the dusts encountered in the marble, gypsum, cement, lime, and limestone trades were the least harmful of inorganic dusts. Some even spoke of their having a beneficial action on tuberculosis. Earlier in the century, however, several Italian observers reported an increased incidence of pulmonary disease in such workers, particularly in cement works. The relationship of cement to chronic pulmonary disease is somewhat obscure. As far as Portland cement is concerned, however, it seems unlikely that cases of pneumoconiosis accompanied by disability occur. This material can hardly be regarded as entirely inert, since it is irritating to the skin and, mildly, to the upper respiratory passages, but it does not appear to produce pulmonary fibrosis of a significant degree. The evidence for this includes the studies of Gardner, Durkan, Brumfiel, 
and Sampson (1939) who examined and radiographed 2,278 workers in cement, of whom over $55 \%$ had been exposed for more than 10 years. No cases of disability were met with and $x$-ray abnormalities were minimal, leading the authors to conclude that the dust risk in this industry was trivial. Dervillée and Carrère (1935), who studied 250 men engaged in making cement and 300 using it, found no evidence of any pulmonary damage from the dust. Parmegianni (1951) carried out $x$-ray examinations of 5,213 workers in the cement industry, of whom 2,473 were miners and quarriers in the marl beds, 1,348 in the asbestos-cement industry, 533 in the manufacture of cement, and 859 were in miscellaneous or unclassified occupations. Cases of silicosis, diagnosed on radiological grounds only, were found, but the incidence was much less than in the other dusty Italian industries and almost confined to those who were in contact not with cement but with the raw materials from which cement is made. The greatest frequency and seriousness of the disease was in the rock-miners and quarriers, in whom there were 181 cases of reticulation $(7 \cdot 4 \%), 21$ cases of nodular silicosis $(0.8 \%)$, and six cases of massive silicosis $(0.2 \%)$. In the cement manufacturing processes, while there were 27 cases of reticulation $(5 \cdot 1 \%)$, no cases of nodular or massive silicosis were discovered.

Bianchi and Turano, according to Forbes and his colleagues (1950), independently studied Italian marble workers and found cases of chronic bronchitis and pulmonary emphysema without much functional impairment or typical $x$-ray changes. Gardner and Dworski (1922) exposed guinea-pigs to marble dust and found that this was soluble in the lung tissue, that it aided calcification in preexisting tuberculous lesions, but that insoluble matter caused a small degree of fibrosis after prolonged exposure, and delayed the resolution of the inflammatory process. Dreessen (1934), out of 422 marble finishers, examined 80 , chosen principally to include men with longer exposures. Sixty had more than 10 years' experience, 48 more than 20 years', 30 more than 30 years', and 11 more than 40 years'. He found that, in a certain number of cases, the dust had produced a mild bilateral linear fibrosis, but no serious lung changes were noted, and there was no disability even after long exposure. $\mathrm{He}$ regarded his findings as essentially negative. Fazzi (1951), however, reports as a case of silicosis a man aged 54 years who had worked for 38 years cutting and drilling with pneumatic tools white marble, the silica content of which was stated not to rise over $0.27 \%$. The $x$-ray findings showed bilateral nodulation, said to be typical of silicosis, but the possibility of concomitant tuberculosis was not entirely eliminated.

Gypsum and alabaster are hydrated calcium sulphates. Manfredi (1949) noted cases of chronic bronchitis and emphysema in a clinical and radiological study of 30 alabaster workers. Gardner (1938) found no evidence of silicosis in men exposed for many years to gypsum dust, and was impressed by the protective action of this dust when mixed with high concentrations of quartz when it was administered to animals. A suggestion that lime exerts a beneficial modifying influence on silicosis is contained in an annotation in the British Medical Journal (1952) as explaining the lesser incidence of silicosis in the Kolar goldfield in South India compared with that in the Witwatersrand. At Kolar the amount of lime in the airborne dust is between 10 and $12 \%$, in the Witwatersrand 0.6 and $4 \cdot 2 \%$. Koelsch and Kaestle (1929), after examining 82 persons who had worked in shell limestone only, concluded that, under certain conditions and over a long period, limestone could cause pulmonary changes within the meaning of " dust lung".

The latest report is that of Raymond, Sivadon, and Conil (1952) who examined 41 limestone quarrymen and stone cutters and found 19 showing some radiological changes, consisting essentially of enlarged hilar regions, increased vascular markings, calcified lymph nodes and aortic enlargement, but without any nodulation or massive shadow formation. Several of the men had symptoms and signs of bronchitis with a tendency to emphysema. The stone consisted almost entirely of calcium carbonate with a total silica content of 1.5 to $4.3 \%$, the free silica being 0.7 to $2.9 \%$. The authors believe that the condition is not accompanied by progressive fibrosis and that limestone dust is allied to Gardner's inert dust.

\section{Limestone Grinding}

The limestone is received at the grinding factory as $\frac{1}{2}$-in. chips and after passing through screens is dried in rotary driers, ground in three successive mills, and finally bagged. The screens produce much dust but this part of the factory is separate from the remainder and no one enters it except for oiling and maintenance when the machinery is at rest. Exhaust ventilation is applied to the rotary driers and to the mills. When I first visited the factory in 1950, the dust removed at these points was simply discharged into the open air above roof level. As the factory is situated in the country this procedure did not cause any nuisance. No exhaust was applied at the bagging points, and considerable quantities of dust were given off at this and other 
places, producing a visible haze in the atmosphere of the workroom and thickly covering the clothing and faces of the workers.

Different grades of fineness of ground limestone are produced. For agricultural purposes it is unnecessary and even inadvisable for the limestone to be ground to a very fine degree, but for stonedusting in mines a relatively fine product is required. Regulations under the Coal Mines Act, 1945, require the limestone to be ground so that all of it passes through a 60 -mesh sieve and not less than $50 \%$ nor more than $75 \%$ passes through a 240 -mesh sieve. Even in producing the coarser grades, however, much very fine dust is evolved. It is unfortunate that it has not been found possible to have studies made of the size, concentration, and constitution of the airborne dust particles.

All 15 employees at this factory normally work in one workroom. As they are employed according to the needs of the moment, all have had experience of all the processes, including the supervision, maintenance, and repair of plant, bagging, loading, and other incidental jobs. While the dust exposure of individual workmen varies somewhat, those having carried out bagging operations to a greater extent than their fellow workers no doubt having had greater exposure, it is impossible to differentiate between the work done by the various men. Their exposure to limestone dust must therefore be taken as differing mainly in regard to their duration of employment. In this account the terms " grinder" and "grinding" relate to men employed and processes carried out in this factory, including the processes incidental to grinding. Of the 15 men, eight had more than five years' exposure to limestone dust, and clinical and radiological examinations were made of these.

\section{Four Other Cases in Grinders}

Case 2.-M. S., aged 50 years, was exposed to limestone dust for 20 years, three years quarrying and 17 years grinding. He had had no previous occupation other than that of butcher. He complained of cough, sputum, and tightness of the chest for four or five years with increasing dyspnoea for three years. $\mathrm{He}$ had bronchitis in March, 1951.

Examination showed a man of average nutrition, good colour, no cyanosis, no finger clubbing. Chest expansion was $2 \frac{1}{2}$ in., equal on both sides, the percussion note was normal, breath sounds were vesicular though harsh at the left apex, and a few crepitations were heard at the right base posteriorly and dispelled by cough. Several sputum tests and a laryngeal swab were negative for M. tuberculosis.

An $x$-ray examination in October, 1951, showed a normal skeleton, heart, and diaphragm. At the right apex, the right and left infraclavicular areas, and the right and left mid-zones were areas of diminished translucency, irregular in density and shape, and shading imperceptibly into more translucent lung tissue without any recognizable margins. The areas between the infraclavicular and mid-zones showed a ground-glass appearance with some very fine stippling. Subsequent films showed little change until May, 1954, when it was seen that the disease had progressed, the areas of diminished translucency were denser with better defined margins, the stippling had beccme coarser, and the picture (Fig. 3) was now typical of pneumoconiosis with advanced massive shadows of category (3)C.

Case 3.-A. M., aged 58 years, a limestone grinder for 28 years, was previously a road repairer for two years, and a kiln drawer at a fireclay brickworks for 14 years. He enjoyed good health except for slight cough attributed to smoking 20 cigarettes daily. He had no sputum or dyspnoea except after heavy smoking. He had no previous respiratory or other serious illness. He was of slight build, of a good colour, with no clubbing. Chest expansion was $1 \frac{3}{4}$ in., the contour was good, movements were equal on both sides, but the percussion note was impaired at the right base posteriorly where also vocal resonance was slightly diminished. Breath sounds were normal, with no accompaniments. Heart sounds were normal. Exercise tolerance was good.

Radiographs showed the heart as normal in size but slightly displaced to the right. The right interlobar septum was thickened, distorted, and displaced slightly downwards. Fluffy irregular shadows were present at both bases, particularly on the right, with smaller, fainter shadows in the mid-zones extending into the upper thirds of the lung fields. Calcified spicules were seen in the left mid-zone as well as in the hilar glands. There were emphysematous bullae at the right base. The general appearance (Fig. 4) was suggestive of complicated pneumoconiosis, category (3)A.

Case 4.-W. H., aged 41 years, had been grinding limestone for 18 years, and before that was a farm worker. He had always enjoyed good health, and regarded himself as very fit at the time of examination. He had occasional cough at night but no sputum or dyspnoea. He looked well, though thin, had a good colour and no clubbing. Chest expansion was $2 \frac{1}{2}$ in., and there were no abnormal signs in the heart or lungs. There was no cervical adenitis, and the throat and mouth were normal except for early pyorrhoea. Exercise tolerance was normal.

Radiographs showed an increased slant of the lower ribs, widening of the intercostal spaces, and the diaphragm depressed to the level of the twelfth rib. The heart shadow was normal. There was generalized reticulo-nodulation in both lung fields, individual elements being small ( 2 to $4 \mathrm{~mm}$.), slightly blurred, and not very dense. The appearance was typical of early simple pneumoconiosis (Fig. 5), category 2 (upper limit).

Case 5.-R. C., aged 48 years, had been grinding limestone for 16 years. Before that he had been employed for five years in a whinstone quarry and for six months in an ironstone pit. His other occupations 


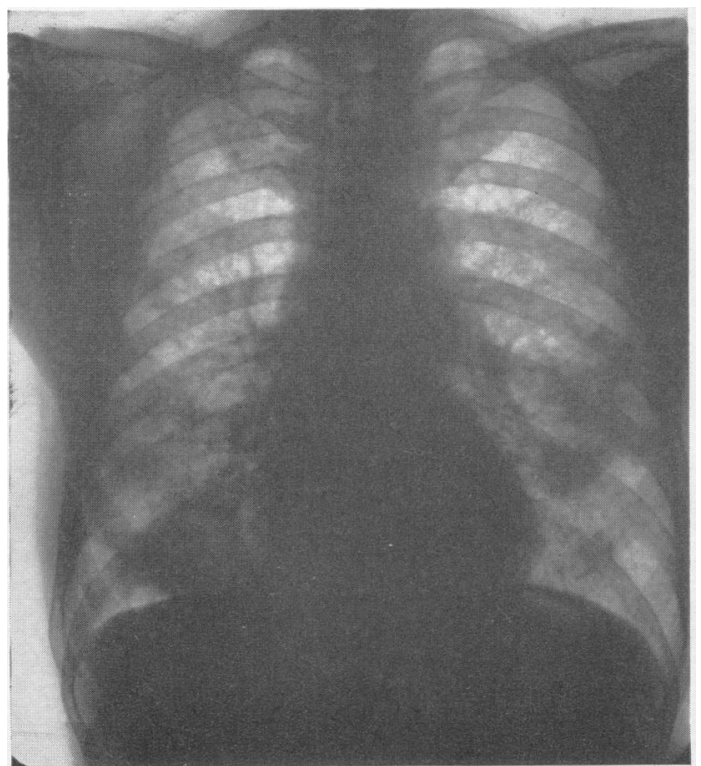

FIG. 3.-Case 2 in May, 1954, aged 53 years; limestone grinder for 20 years.

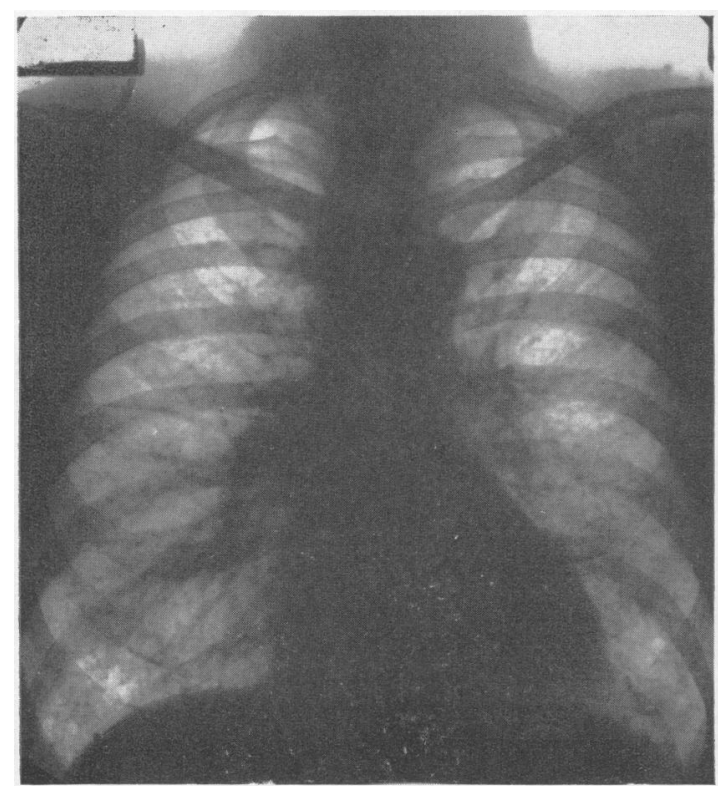

Fig. 5.-Case 4 in September, 1951, aged 41 years; limestone grinder for 18 years.

were not dusty. His previous health had been good, he felt fit and had no symptoms whatever. He looked healthy, and musculature, colour, and nutrition were good. No finger clubbing was seen. He had a congenital (probably familial) deformity of the sternum. Chest expansion was 2 in., and percussion and

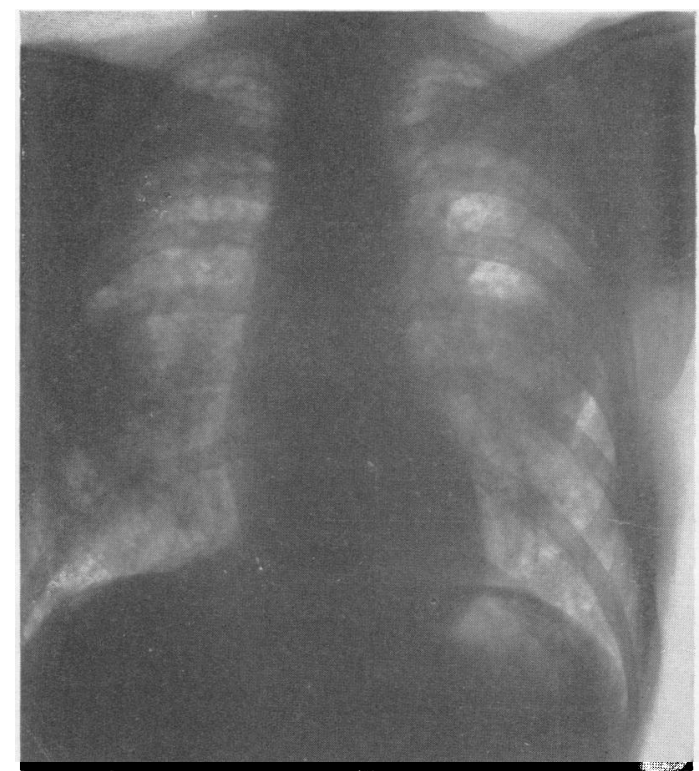

Fig. 4.-Case 3 in September, 1951, aged 58 years ; limestone grinder for 28 years.

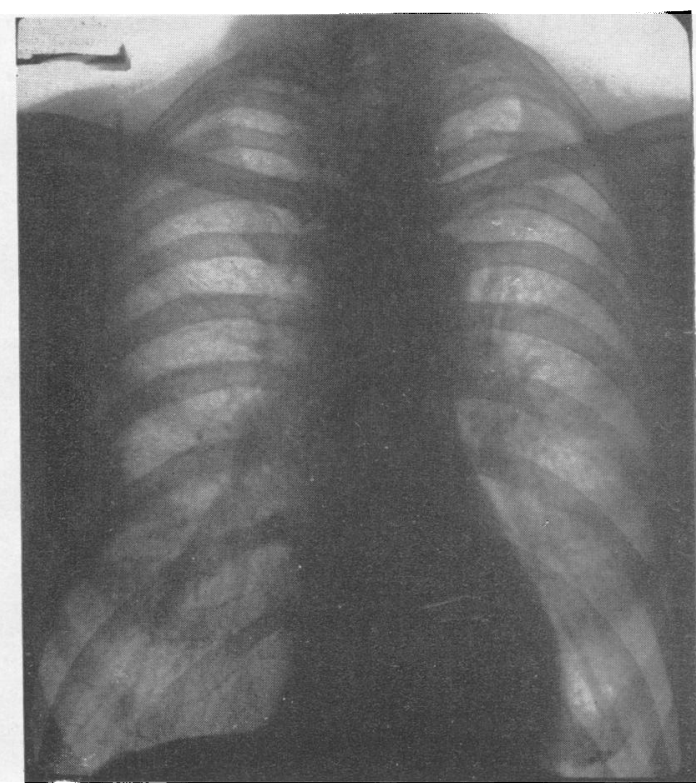

Fig. 6.-Case 5 in September, 1951, aged 48 years; limestone grinder for 16 years.

auscultation of the lungs normal. Heart sounds were normal, and no abnormalities of nose, throat, or neck glands were found. Exercise tolerance was good.

Radiographs showed normal skeleton and heart shadows. The left dome of the diaphragm was blurred and the left costcphrenic angle obscured. Reticulo- 
nodulation in both mid-zones, nodulation most marked on the left, was seen, and some increase in the hilar shadows. The appearance (Fig. 6) was that of simple pneumoconiosis, category 3 .

\section{Grinders without Pneumoconiosis}

The remaining four limestone grinders were found not to have pneumoconiosis.

W. L., aged 44 years, had been a limestone grinder for seven years. He was unable to give an accurate account of previous occupations which had included farm work, labouring in a steel-rolling mill, and work in a whinstone quarry. He had had two attacks of pleurisy in adult life, otherwise his health was always good. He had morning cough, but no sputum, or dyspnoea. He was thin, of a good colour, with no finger clubbing. Chest expansion was $2 \frac{3}{4}$ in., and no abnormalities were detected on examination of the heart, lungs, cervical glands, or throat.

Radiographs showed slightly accentuated lung markings and increased translucency of both bases but no parenchymal opacities.

D. B., aged 39 years, had been a limestone grinder for 20 years with no previous exposure to dust. He enjoyed excellent health, had no symptoms, looked very fit, had a chest expansion of $3 \frac{1}{4}$ in., and on examination appeared quite normal.

Radiographs were normal apart from some increase in vascular markings at both bases.

F. G., aged 43 years, had spent his entire working life either limestone grinding (approximately 15 years) or whinstone quarrying (about 14 years). He had always had good health. He had morning cough and sputum but no dyspnoea. No abnormalities were found on clinical examination; chest expansion was $2 \frac{1}{2}$ in.

The $x$-ray appearances were normal except that the dome of the diaphragm was considerably below the level of articulation of the twelfth rib with the spine.

E. F., aged 39 years, had been grinding limestone for five and a half years, but had had no other exposure to dust. He had always had good health and was symptomless. Clinical and radiological examinations were quite normal.

\section{Composition of Limestones}

Limestones vary widely regarding the amount of calcium carbonate present, and many contain considerable quantities of other substances. A high calcium carbonate content is not, of course, essential for limestones used in the building industry, for roadstone, or for the manufacture of rock wool. For agricultural and chemical purposes, however, it is not economic to work low-grade limestones, and for stone dusting in mines only limestones with a low silica content should be used. Forbes and his colleagues (1950) say that they have confidential information that some coal-mining companies (presumably in America) " have had difficulty with employees engaged in the rock-dusting work; these have complained that breathing the large quantity of fine rock dust $(90 \%$ or more limestone and usually less than $5 \%$ silica) has caused serious illness". Beal, Griffin, and Nagelschmidt (1953) analysed 30 samples of limestone used for stone dusting in mines, and found that the quartz content was less than $3 \%$ in 26 , between 3 and $20 \%$ in three, and over $60 \%$ in the remaining sample which was probably sent in error. They suggest that limestones used for stone-dusting should be restricted to those with less than $3 \%$ of quartz, or $5 \%$ of total silica, and point out that legislation exists in certain countries, notably Australia, Germany, and Holland, to prevent the use of unsuitable materials for this purpose.

The particular limestone handled at this grinding factory comes from an outcrop of a bed of the Lower Limestone Group of the Carboniferous Limestone Series. The thickness of the seam is about $20 \mathrm{ft}$., and the overburden is slight. According to Simpson (1943) it is an excellent quality limestone, pale grey with occasional bands of darker stone. It is not burned for lime but used for agricultural purposes in the raw ground state, for stone dusting in mines, for poultry grit, and for road chips. He gives as a typical analysis :-

$\begin{array}{lllllr}\mathrm{CaO} & \ldots & \ldots & \ldots & \ldots & 51.44 \% \\ \mathrm{CO}_{2} & \ldots & \ldots & \ldots & \ldots & 40.62 \% \\ \mathrm{SiO}_{2} & \ldots & \ldots & \ldots & \ldots & 4.93 \%\end{array}$
with amounts of $\mathrm{Al}_{2} \mathrm{O}_{3}, \mathrm{Fe}_{2} \mathrm{O}_{3}, \mathrm{MgO}, \mathrm{H}_{2} \mathrm{O}, \mathrm{MnO}$, and $\mathrm{FeS}_{2}$ all between $0 \cdot 1$ and $0.9 \%$ and $\mathrm{Na}_{2} \mathrm{O}$, $\mathrm{K}_{2} \mathrm{O}$, $\mathrm{TiO}_{2}$, and $\mathrm{P}_{2} \mathrm{O}_{5}$ less than $0.1 \%$ The amount of silica recorded represents total silica. This varies considerably and is often higher than that quoted. The results of analyses of three samples of this limestone taken recently at different times were as follows :-

\begin{tabular}{|c|c|c|c|}
\hline & Sample 1 & Sample 2 & Sample 3 \\
\hline $\begin{array}{l}\text { Total silica } \\
\text { Acid insoluble material... } \\
\text { Free silica }\end{array}$ & $\begin{array}{r}11 \cdot 8 \% \\
1.8 \%\end{array}$ & $\begin{array}{l}9 \cdot \overline{6} \% \\
5.1 \%\end{array}$ & $\begin{array}{l}20 \cdot 8 \% \\
11.5 \%\end{array}$ \\
\hline
\end{tabular}

\section{Three Cases in Miners}

Since discovering these cases in grinders, I have discussed the condition with doctors in various localities where limestone is worked, and have obtained information of three further cases of pneumoconiosis, one of which had proved fatal. The three men affected had been limestone-miners, the limestone they worked being of a different seam and in a different locality from that worked by the aforementioned grinders.

Case 6.-W. P. was aged 65 years at death. From the age of 12 to 32 he worked in a limestone quarry, then 


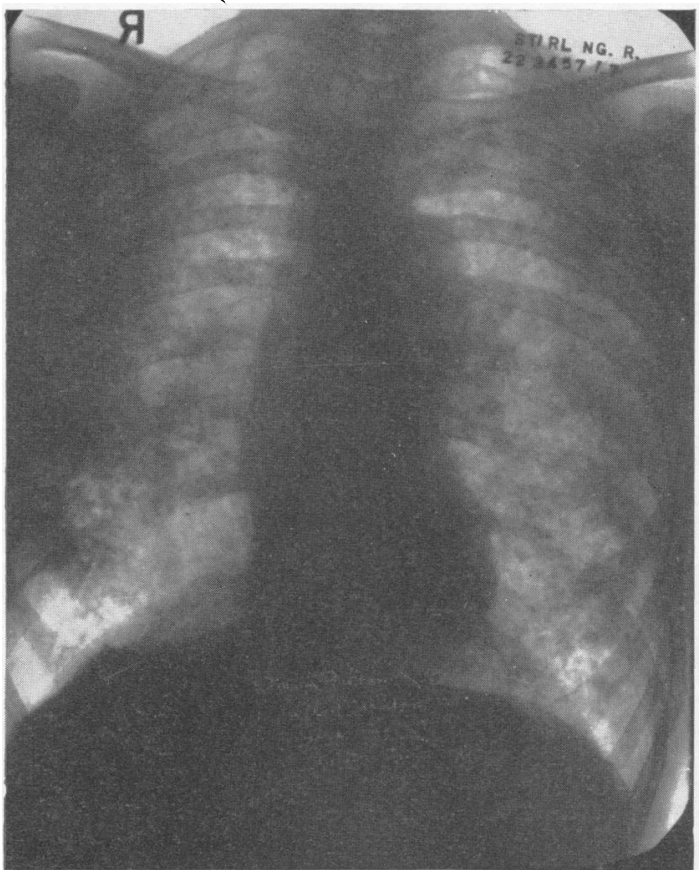

Fig. 7.-Case 6 in February, 1945, aged 63 years ; limestone-miner and quarryman for 39 years.

until the age of 41 in a coal-mine, chiefly as a repairer, and for the following 19 years as a limestone-miner, leaving this work at the age of 60 because of dyspnoea. After two years as a munitions storekeeper he finally gave up work. His exposure to dust was therefore 39 years as a limestone worker and nine years as a coalminer.

He had had good health until the onset of dyspnoea about the age of 55. At the medical examination two years before his death he was found to be thin, pale, of poor musculature, and suffering from dyspnoea, cough, and expectoration, chest expansion was diminished, the respiratory murmur harsh and high-pitched, the arteries were thickened and tortuous, and there was cardiac arrhythmia. $X$-ray examination showed normal skeletal and heart shadows, the mediastinum considerably broadened, adhesions of the right dome of the diaphragm, extensive dense opacities in both lungs mainly in the outer peripheral zones, and marked translucency at the bases. The opacities were not entirely homogeneous but could be seen to have a nodular basis, and nodules of varying sizes were seen elsewhere throughout the lung fields. The appearance (Fig. 7) was that of very advanced silicosis with massive shadows, category (3)D.

Necropsy confirmed the presence of silicosis.

The following description of the pleurae and lungs has been taken from the necropsy report :-

Pleurae.-Both pleural sacs contained about $100 \mathrm{ml}$ of clear, yellow fluid. Extensive and firm fibrous adhesions bound parietal and visceral pleurae together at the apex of the left lung and over the antero-lateral surface of the right upper lobe. The interlobar fissures of the right lung were obliterated almost completely by fibrous adhesions.

Lungs.-Both lungs (R. 1,500 g., L. 1,200 g.) were large, voluminous, and showed well marked emphysematous bullae especially along the lower part of the anterior borders, their inferior borders, and on their diaphragmatic surfaces. They were dark in colour but anthracosis was not marked.

The upper lobe, most of the middle lobe, and the upper two-thirds of the lower lobe of the right lung were consolidated. The lung tissues in these areas had the consistency of tough indiarubber. A small area at the right apex and another in the lower third of the lower lobe were much less firm, and small firm nodules some 2 to $3 \mathrm{~mm}$. in diameter could be felt beneath the pleura and in the parenchyma. The lung was sectioned with some difficulty owing to the fibrotic nature of the tissue, and the consolidation was seen to be due to the confluence of countless grey, fibrous; silicotic nodules giving the lung a dark, slate-grey colour. A little mucopus exuded from the smaller bronchi, but there was no evidence of tuberculosis, bronchopneumonia or bronchiectasis to the naked eye. The left lung showed similar features, but the consolidation was less extensive, involving the lower part of the upper lobe and the upper two-thirds of the lower lobe. A white fibrotic scar was seen situated subpleurally in the interlobar fissure near the apex of the lower lobe. Section revealed marked involvement of the whole lung by silicosis, with confluence of the nodules in the areas indicated. There was no evidence of tuberculosis.

The mediastinal glands were not enlarged.

Heart (report abridged).-The right ventricle showed marked hypertrophy and dilatation; the myocardium showed no evidence of recent or old infarction and the coronary vessels no atheroma.

Histology.-Sections taken from the consolidated portions of the lung show complete replacement of the normal lung parenchyma by confluent, dense, and in places, hyaline, fibrotic tissue nodules characteristic of advanced silicosis. Accompanying these changes is a moderate degree of anthracosis. Many of the arteries and arterioles show well marked endarteritis.

Sections taken from the unconsolidated lung show scattered silicotic nodules of various sizes, having a perivascular and peribronchial arrangement, lying in lung tissue which shows well marked emphysema. The alveolar capillaries are congested, and most of the alveoli contain a variable number of mononuclear cells containing both carbon and silica* particles. The walls of the smaller bronchi and bronchioles are acutely inflamed, and their lumen filled with an inflammatory exudate which contains a high fibrin content. The aveoli in their immediate neighbourhood also contain inflammatory exudate, the appearance being that of acute bronchitis and bronchiolitis with early terminal bronchopneumonia (Figs. 8 and 9).

* Seven years had elapsed since this death occurred and I have not found it possible to ascertain how the particles were identified as silica. It does not seem that micro-incineration was carried out. 


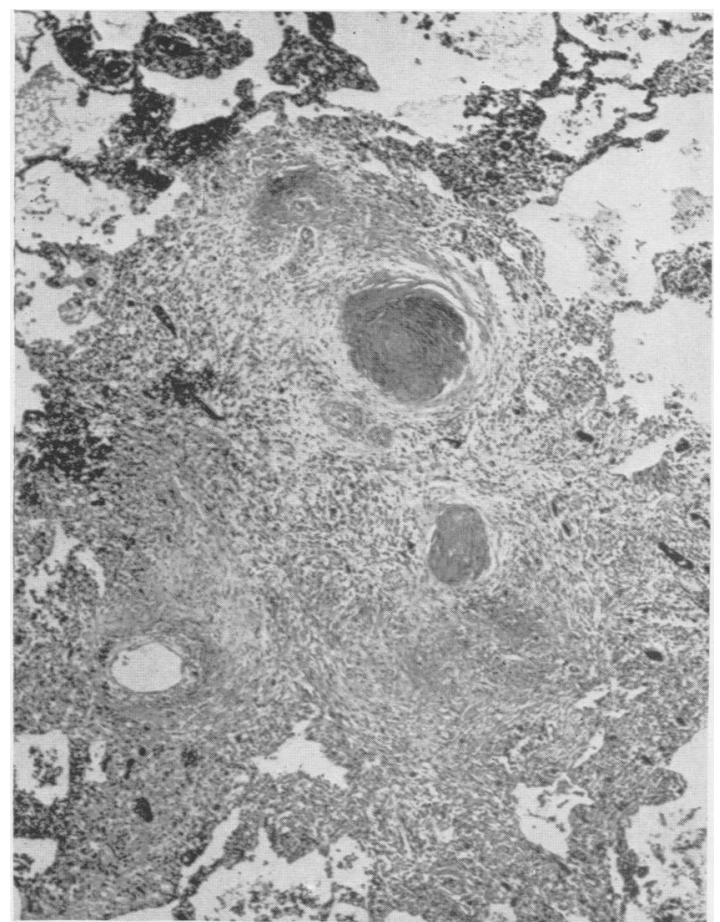

FIG. 8.-Case 6 : confluent silicotic nodules. $\times 30$.

Case 7.-J. L., aged 47 years, had been a gardener's boy and van boy for three years, carting limestone rock and rubble in a quarry two years, a limestone-miner for 23 years, a colliery surface worker for six months, and a coal-miner for six months. He had always had excellent health apart from pneumonia at the age of 14 years. He had pain in the left side of the chest in 1946, thought to be muscular in origin, and was not radiographed. Dyspnoea began to be noticed about 1946 ; in 1948 he resigned from a military pipe band because of breathlessness when playing bagpipes. Dyspnoea increased and slight cough and sputum appeared. Examination showed him to be a well built man of excellent musculature and of good colour. There was no finger clubbing. The chest was symmetrical, expansion 2 in., the percussion note normal, and auscultation revealed only a few sibilant rhonchi at the right base on deep inspiration. The heart was normal, there was no adenopathy, and the nasal passages were clear.

Radiographs showed a normal skeleton, heart, and diaphragm, and bilateral nodulation in both lungs principally in the upper two-thirds affecting mainly the periphery and showing a tendency to coalesce, category 3. The Pneumoconiosis Medical Panel of the Ministry of National Insurance confirmed the diagnosis of pneumoconiosis and the presence of disability which they assessed at $20 \%$ (Fig. 10).

Case 8.-A. L., aged 69 years, the father of Case 7, after spending five years as a grocer's assistant and two years on road repairs, had been a coal-miner working

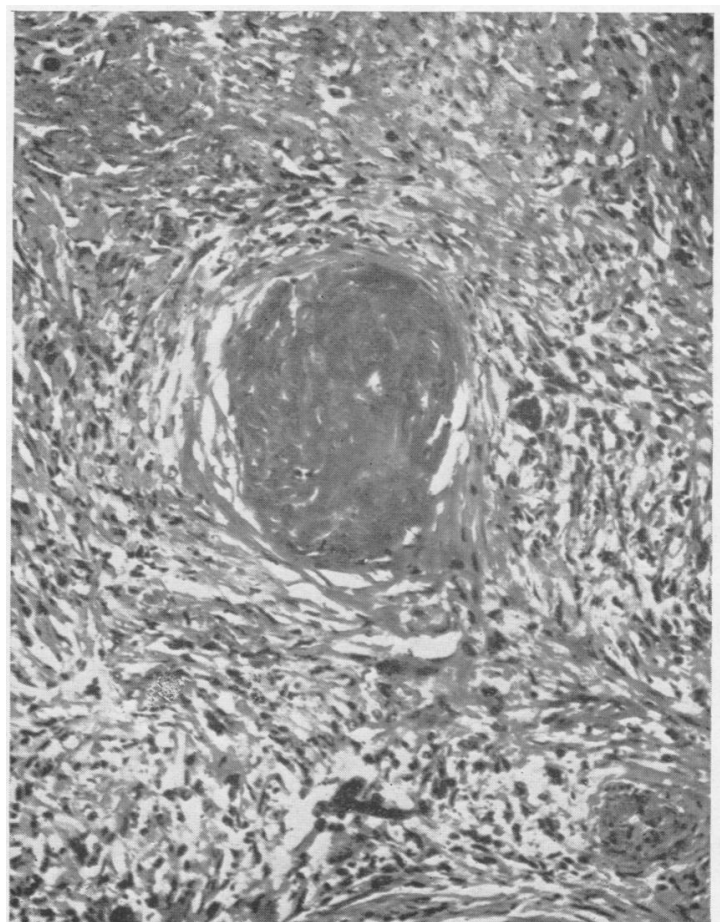

Fig. 9.-Case 6 : silicotic nodule. $\times 140$.

underground for seven years. After three years in the Army (1915-18) he became a limestone-miner, spending 36 years at this work and a further two years grinding limestone rock. He retired in November, 1951, because of ill-health which had been developing for about 10 years. His first and main symptom was dyspnoea. In the last few years, in addition to bringing on breathlessness, exertion led to syncopal attacks with loss of consciousness. Other symptoms consisted of cough, sputum, and chest pain over the lower sternum and both lung bases anteriorly. His previous health had always been good. Examination showed him to be rather corpulent and pale ; he had no finger clubbing and no cyanosis; he had obvious dyspnoea when walking on the level but no dyspnoea at rest. Chest expansion was $1 \frac{1}{2}$ in. The percussion note was slightly hyper-resonant anteriorly, and breath sounds were normal but with numerous medium fine crepitations at both bases persisting after cough. Heart sounds were normal but the rate was very irregular in time and force. No other significant abnormalities were found.

An $x$-ray film taken on February 12, 1951, showed a normal skeletal shadow, a heart much enlarged to the right, and the left diaphragm raised. Throughout both lung fields there were multiple, fairly dense, soft-edged shadows differing in size and tending to confluence at the left base. The appearance (Fig. 11) was very suggestive of advanced simple pneumoconiosis of category 3 with considerable cardiac enlargement. He, also, had been granted a certificate by the Pneumoconiosis Medical 


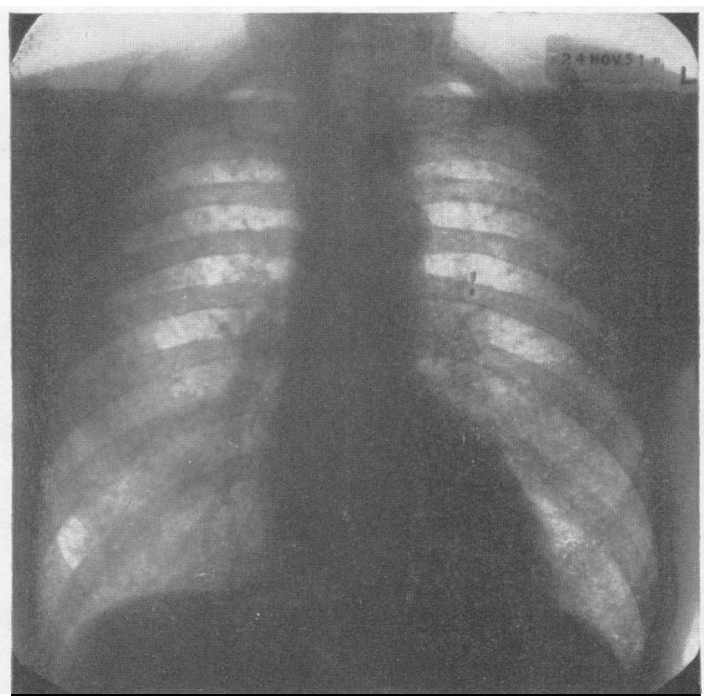

Fig. 10.-Case 7 in November, 1951, aged 47 years ; limestoneminer and quarryman for 25 years.

Panel on account of pneumoconiosis with disability from that disease rated at $60 \%$.

These three miners all worked in the same limestone mine. This limestone, like that to which the grinders were exposed, forms a bed of the Lower Limestone Group of the Carboniferous Limestone Series. Its thickness is about $50 \mathrm{ft}$. but the upper $30 \mathrm{ft}$., being more impure than the lower $20 \mathrm{ft}$., is not extracted. This lower portion is a dark grey, fossiliferous limestone of uniformly high quality, yielding on analysis $94.09 \%$ calcium carbonate, $1.95 \%$ magnesium carbonate, and $2.53 \%$ of insoluble residue (Robertson, Simpson, and Anderson, 1949). Much of it is used to make lime for agricultural and building purposes. Ground limestone is also produced, some of which is used for stone-dusting in coal-mines.

Recent samples, however, indicate much greater amounts of silica.

\begin{tabular}{|c|c|c|c|c|}
\hline & \multicolumn{2}{|c|}{ Sample 1} & Sample 2 & Sample 3 \\
\hline & $\begin{array}{l}\text { Top } \\
\text { Stone }\end{array}$ & $\begin{array}{l}\text { Bottom } \\
\text { Stone }\end{array}$ & & \\
\hline Total silica $(\%)$ & $14 \cdot 1$ & $7 \cdot 1$ & - & - \\
\hline $\begin{array}{l}\text { (\%) } \\
\text { Acid-insoluble materiai }\end{array}$ & 11.9 & $6 \cdot 0$ & - & - \\
\hline 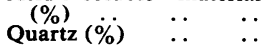 & 二 & 二 & $\begin{array}{r}12 \cdot 1 \\
6.2\end{array}$ & $\begin{array}{l}9 \cdot 3 \\
3.9\end{array}$ \\
\hline
\end{tabular}

The main details of the cases are summarized in Tables 1 and 2.

\section{Discussion}

Eight cases of pneumoconiosis in limestone workers are described, five in grinders and three in

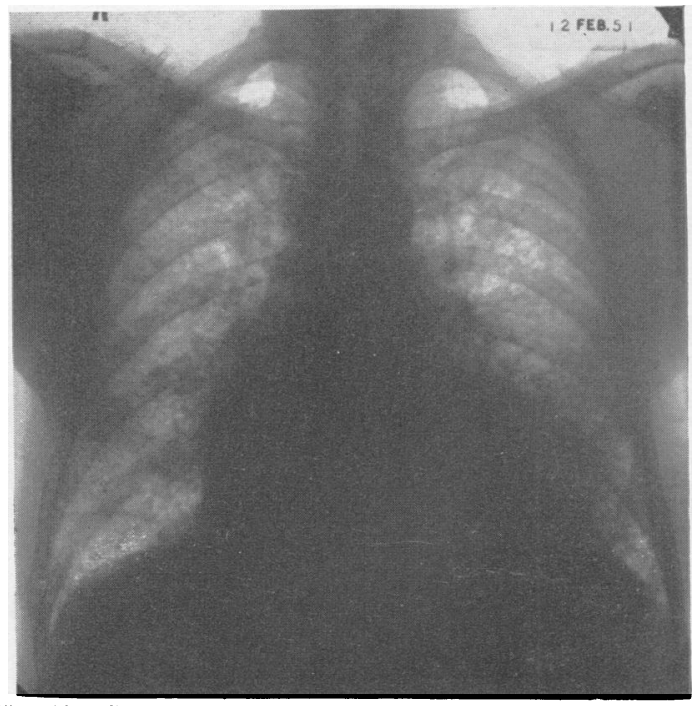

Fig. 11.-Case 8 in February, 1951, aged 69 years ; limestone-miner for 36 years and grinder for two years.

miners. The grinders were aged between 41 and 58 years and had been employed in this work for periods of from 16 to 28 years, the mean being 21.6 years. The miners were aged 46 to 69 years and had 25 , 38 , and 39 years' exposure to limestone dust. Taking the grinders and miners together, the mean duration of employment of the eight cases was $26 \cdot 1$ years.

There does not seem to be the slightest doubt that the pneumoconiosis has been produced by limestone dust. Three of the men, Cases 2, 4, and 7, had no history of exposure to any industrial dust other than limestone, and in one other, Case 1, such exposure amounted only to six months as a whinstone quarryman. In all the remaining cases the exposure to limestone was considerably in excess of exposures to other dusts, which cxposures would have been unlikely, by themselves, to have given rise to the degree of pneumoconiosis which existed in the particular persons affected.

Three of the limestone grinders had no obvious disability; of the remaining five pneumoconiosis cases, three were partially disabled, one was totally disabled, and one had died of the disease. Symptoms were slight or absent in those who were not disabled; in the others, dyspnoea was the most prominent symptom and cough and sputum were also present. $X$-ray findings were variable ; large, massive shadows were present in the fatal case, nodulation in three, reticulo-nodulation in two, and reticulation with diminished translucency and fluffy shadows in the remaining two cases. In the fatal 
TABLE 1

LIMESTONE WORKERS WITH PNEUMOCONIOSIS

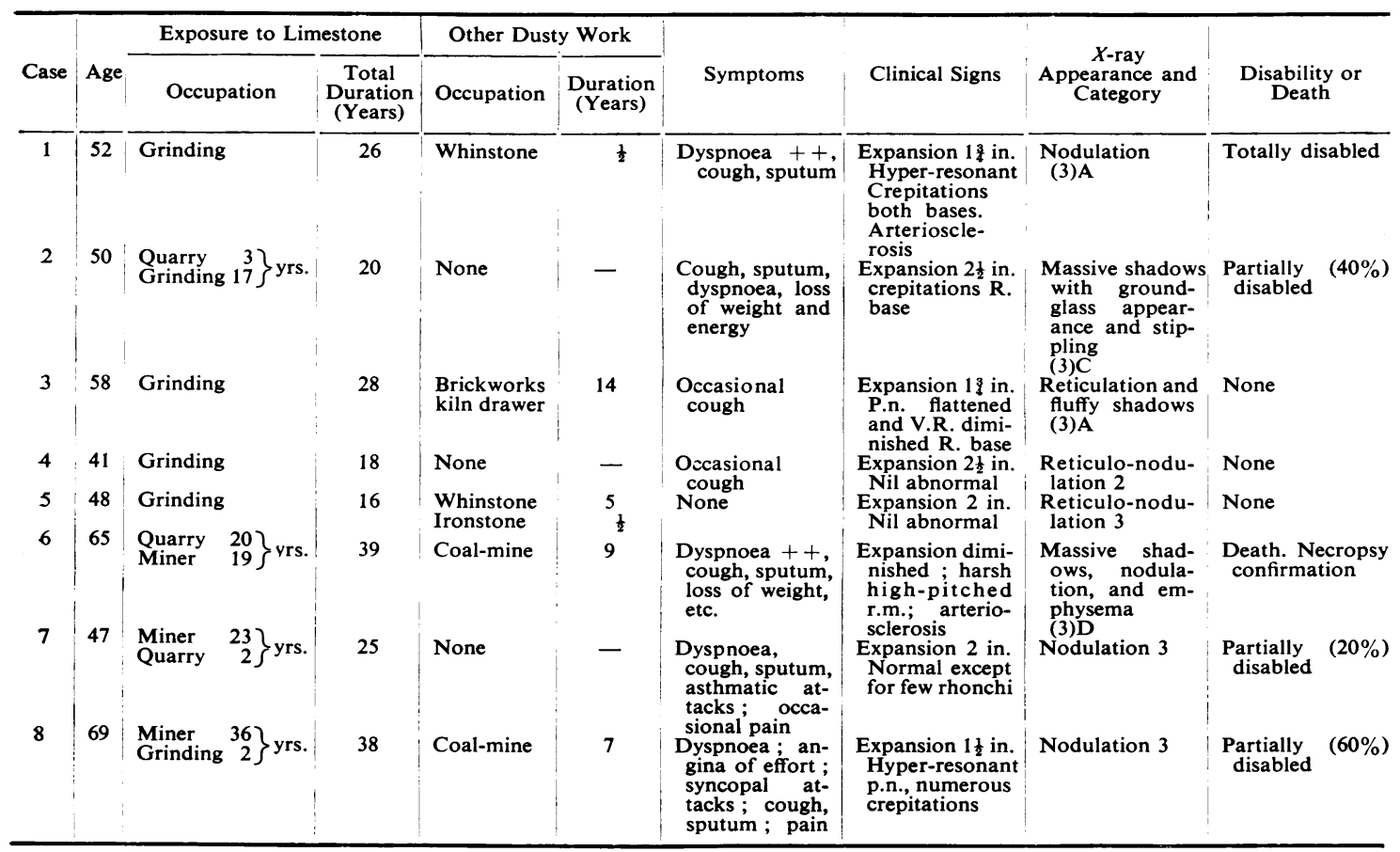

TABLE 2

LIMESTONE WORKERS WITHOUT PNEUMOCONIOSIS

\begin{tabular}{|c|c|c|c|c|c|c|c|c|c|}
\hline \multirow[b]{2}{*}{ Initials } & \multirow[b]{2}{*}{ Age } & \multicolumn{2}{|c|}{ Exposure to Limestone } & \multicolumn{2}{|c|}{ Other Dusty Work } & \multirow[b]{2}{*}{ Symptoms } & \multirow{2}{*}{\multicolumn{2}{|c|}{ Clinical Signs }} & \multirow[b]{2}{*}{ Radiograph } \\
\hline & & Occupation & $\begin{array}{c}\text { Duration } \\
\text { (Years) }\end{array}$ & Occupation & $\begin{array}{c}\text { Duration } \\
\text { (Years) }\end{array}$ & & & & \\
\hline W. L. & 44 & Grinding & 7 & Whinstone & $?$ & Morning cough & 23 in. expansion. & Nil & Basal translucency -? \\
\hline D. B. & 39 & Grinding & 20 & None & - & None & $3 \frac{1}{4}$ in. expansion. & Nil & Normal except increased \\
\hline F. G. & 43 & Grinding & 15 & Whinstone & 14 & Cough, occasional & $2 \frac{1}{2}$ in. expansion. & Nil & Normal (diaphragm \\
\hline
\end{tabular}

case post-mortem examination showed extensive nodular fibrosis of the lungs.

The noxious constituent of the limestone can only be $(a)$ the calcium carbonate, $(b)$ the free silica, (c) the combined silica or silicates, or $(d)$ one of the other constituents. The main constituent is calcium carbonate but there seems absolutely no evidence that this could produce pulmonary fibrosis. Silicates are present in varying amounts up to $10 \%$ in the samples analysed and must be considered as possible aetiological factors. Professor George, of Glasgow University, has suggested that acicular crystals of clay materials may exist in the limestone and might act like asbestos fibres. This is an interesting theory, and the role of silicates in producing limestone pneumoconiosis seems worthy of further inquiry, being closely associated with the question of silicatosis due to other dusts. At present, however, I consider that any action that the silicates in limestone might have in producing fibrosis of the lungs must be subordinate to that of free silica. In fact, in some cases at least the lesion seems to be a classical silicosis. Histological examination of sections of the lungs in the fatal case shows lesions composed of dense fibrous tissue with a typical whorled appearance, very suggestive of the action of silica alone unmodified by other dusts. In certain cases, notably Cases 1,7 , and 8 , the $x$-ray 
appearance of discrete nodulation suggests a silicotic lesion. On the other hand, the rather atypical appearance of the $x$-ray film of the patient in Case 2, who had no exposure to other dust, suggests that in some cases the lesion may not be a "pure" silicosis but may be a modified silicosis or mixeddust pneumoconiosis. The $x$-ray appearance of the lungs of Case 3 was also suggestive of a modified lesion, but this man, in addition to 28 years' exposure to limestone dust, had had 14 years' exposure to fireclay dust, so that in his case the modifying influence may have been external to the limestone.

Exposure to limestone dust, in certain processes at least, carries a definite risk of pneumoconiosis. The severity of the risk, shown by the occurrence of five cases in a group of nine limestone grinders with more than five years' experience, and by the comparatively short period of exposure of the affected men (average 21.6 years), appears to be rather astonishing in view of the low quartz content of the material. Such an exposure period would seem to indicate a degree of risk comparable to that of many workers exposed to much more highly siliceous dusts, for instance sandstone dressers and steel fettlers. It is surprising, too, that so little information about the condition occurs in the literature. In comparison, for example, with the granite industry (granite has a quartz content of 15 to $35 \%$ ), the risk of silicosis is well known, but Mair (1951), in an examination of 518 workers exposed to a dust hazard in granite dressing, found that to produce the minimum degree of radiological change, an average of 32 "dust years" was necessary, while reticulation required 38 , nodulation 40 , and massive shadows 42 years. In limestone mining, too, the risk would appear to be almost as great as in grinding, but I cannot estimate the incidence having no knowledge of the number of men at risk. The explanation lies almost certainly in the extremely heavy concentration of the dust cloud to which the limestone workers have been exposed.

Incidentally the view is held in some quarters that calcium carbonate dust has a beneficial action on quartz, decreasing its toxicity. The findings of Gardner (1938) have already been mentioned. Landwehr (1947) states that the higher the calcium content, the less dangerous is the rock, and Forbes and his colleagues (1950) refer to the possibility that dusts of calcium minerals may belong to the so-called "protector" dusts. The occurrence of these cases of silicosis as a result of exposure to dust containing between 1.8 and $12.1 \%$ of free silica and 85 to $95 \%$ of calcium carbonate would not appear to indicate any inhibitory effect of the latter material.

\section{Summary}

Attention is drawn to the occurrence of cases of pneumoconiosis in limestone workers.

This pneumoconiosis is associated with fibrosis of the lungs and, in advanced cases, with disability.

The lesion produced is almost certainly silicosis, due to the free silica content of the limestone.

The pneumoconiosis hazard, in the mining and grinding of at least certain limestones, is considerable, in spite of the relatively low free-silica content.

Whether or not calcium carbonate can modify the action of silica, it would not appear, judging from these observations, to have any inhibitory'effect.

I am greatly indebted to many colleagues for help in my inquiries. In particular, acknowledgments are due to Dr. A. K. Turnbull for drawing my attention to Case 1, to Professor Drennan and Dr. A. D. Bain for copies of the pathological reports and photomicrographs of Case 6, to Dr. J. Simpson for the loan of the $x$-ray film of Case 6, to Dr. H. W. O. Frew for carrying out the $x$-ray examination of the grinders, to Dr. James Innes for drawing my attention to Case 7, to Dr. L. W. Laurenson for information and permission to examine Cases 7 and 8 , to Dr. W. S. Shearer for the loan of the $x$-ray films of Cases 7 and 8, to Professor George for many useful suggestions and for reviewing my notes on the geology of limestones, to Dr. G. Nagelschmidt and the Government Chemist for permission to use the results of their analyses of samples of limestone, to Dr. A. Meiklejohn and Dr. J. Black for helpful criticism and advice, and to Dr. E. R. A. Merewether for his stimulating interest.

\section{REFERENCES}

Beal, A. J., Griffin, O. G., and Nagelschmidt, G. (1953). Ministry of Fuel and Power. Safety in Mines Res. Estab. Res. Rep. No. 72, Sheffield.

British Medical Journal (1952). 1, 965.

Dervillé, P., and Carrère, P. (1935). Méd. du Trav., 7, 244.

Dreessen, W. C. (1934). Publ. Hlth Rep., Wash., 49, 724

Fazzi, P. L. (1951). Folia med., Napoli, 34, 366 .

Forbes, J. J., Davenport, S. J., and Morgis, G. G. (1950). Review of Literature on Dusts. Bull. 478, U.S. Dept of Interior, Bureau of Mines, Washington.

Gardner, L. U. (1940). Silicosis : Proc. int. Conf., Geneva, 1938,

- pp. 8-9. I.L.O. Studies and Reports, Series F., no. 17. pp. 8-9. I.L.O. Studies and Reports, Series F.,

and Dworski, M. (1922). Amer. Rev. Tuberc., 6, 782. J. industr. Hyg., 21, 279.

Koelsch, F., and Kaestle, K. (1929). Quoted by Forbes, J. J., Davenport, S. J., and Morgis, G. G. (1950).

Landwehr, I. (1947). Atlas zur Charakteristik der Silikosegefährlichkeit von Gesteinen und nutzbaren Mineralien deutscher Lagerstätten (Treatise on the Characteristics and Silicosis Hazard of Rocks and their ingredients found in German Mines). Translated by M. C. S. Kennedy. Bergbau-Berufs-

Mair, A. (1951). Edinb. med. J., 58, 457.

Manfredi, M. S. (1949). Settim. med., 37, 193. [Abs. Arch. industr. Med., (1950) 2, 607, ].

Parmeggiani, L. (1951). Rass. Med industr, 20, 400.

Raymond, V., Sivadon, A. and Conil, P. (1952). Arch. Mal. prof., 13, $16 \ddot{9}$.

Robertson, T., Simpson, J. B., and Anderson, J. G. C. (1949). The Limestones of Scotland. Memoirs of the Geological Survey; Special Reports on the Mineral Resources of Great Britain, Vol. XXXV, (Dept. Scientific Indust. Res.), Edinburgh.

Simpson, J. B. (1943). Limestones of Scotland. Area II, West-Central Scotland. Geological Survey of Great Britain : Scotland (Wartime Pamphlet No. 13). Dept. Scientific Indust. Res., London.

Third International Conference of Experts on Pneumoconiosis Sydney, 1950 (1953). Report of Proceedings. International Labour Office, Geneva. 